\title{
STUDENTS' PERCEPTION OF THE USE OF STORY TELLING TECHNIQUE TO IMPROVE PRONUNCIATION SKILL
}

\author{
Nukmatus Syahria \\ Email:mamaafran@gmail.com \\ Universitas PGRI Adi Buana Surabaya
}

\begin{abstract}
The complexities of skills in the Pronunciation created many hindrances for the students in mastering the Pronunciation Practice subject. Most of the first semester students of Adi Buana University were failed during the mid test since they have very little background knowledge of the Pronunciation skills and they tend to get bored during the teaching and learning activities. The writer tried to apply the story telling technique in the middle of the semester to foster the pronunciation skills to the first semester undergraduate students of English Department as well as to arouse the students' motivation in learning pronunciation. The writer used questionnaire to collect the data and each item in the questionnaire was analyzed and calculated then presented in the percentage to find out the students' perception toward the use of storytelling technique. The result showed a significant progress on the final test score of the students and it also gave a good impact toward the students' motivation in learning Pronunciation.
\end{abstract}

Key words: pronunciation skills, story telling

\section{INTRODUCTION}

Besides listening, reading, and writing, pronunciation holds an important role in learning English. Most of the teaching and learning English in Indonesia is based on the grammar and vocabulary development. Since in the Junior High School, the students were led by the teachers to understand more about grammar instead of the pronunciation. Many of Indonesian students just knew about pronunciation in the university level or in the language course. In fact, pronunciation is a crucial part which has to be learned in English so that the students can pronounce every word in English precisely and clearly. The misuse of pronunciation can lead to confusion with the 
person we are talking with. In the reality, most of the Indonesian students have difficulties to imitate the foreigners' pronunciation. This happened because many Indonesian students have insufficient knowledge of phonology and phonetic systems of the English language since the students never receive these lessons in their primary or secondary school. This situation is worsened by the first language interference of the students' mother tongue.

However, teaching pronunciation in the university level can be a tough part for the lecturers especially in Indonesia because the students have little schemata about it and the students are mostly influenced by their mother tongue. Second, the university students tend to get bored easily during the pronunciation class since the lesson was mostly on drilling and imitating the lecturers. Therefore, the writer is interested to find a simple but fun teaching technique for the students in order that the students will feel motivated in learning pronunciation and to boost the students' mastery in pronunciation skills. Turney, 1992; 32 stated "motivation plays an important role in the teaching and learning process. It is one of the factors that determine the success of a second language acquisition". While Monica (2001) pointed "there is a correlation between the intrinsic and extrinsic motivation in supporting the students in their effort to become successful English learners". Intrinsic motivation comes from within the students while on the other hand extrinsic motivation comes from outside, such as the intention of receiving a good mark or a reward from the teacher. The writer tried to apply the story telling technique in teaching pronunciation for the university students. One of the reason of why the writer chose story telling because in the story telling the students were not only learned about the new vocabulary but they were also learned about how to pronounce the words well, how to use repetition, rhymes as well as how to use the right intonation in a story in order that the listeners will enjoy the story. In simultaneously, it will help to arouse the students' imaginative thought, because the students will also learn about how to develop the story so that their story is not only interesting but also meaningful enough for the listeners. 
Based on the background above, this research attempts to answer the question of how the students' responses toward the use of story-telling technique.

\section{SCOPE AND LIMITATION OF THE STUDY}

This study focused on finding out on how the students perceived the use of story-telling technique in their learning of pronunciation. The limitation of the study was the first semester of undergraduate students of English Education Department of Adi Buana University Surabaya.

\section{THE IMPORTANCE OF STORY TELLING}

Pellowski, Anne (1977) defines storytelling as "the art or craft of narration of stories in prose or verse, as performed or led by one person before a live audience; the stories narrated may be spoken, chanted, or sung with or without musical, pictorial or other companion and may be learned from oral, printed or mechanically recorded sources: one of its purposes may be that of entertainment". Furthermore Peterson, Martin (2003) claims storytelling is "an activity which requires a certain level of interaction between the storyteller and the audience and between individual and listener". As there is a great interaction between the story teller and the audience therefore story telling can be one of a good way to practice the social communication and it is also very helpful for the shy and less active students because story telling makes students feel comfortable and relax during their study. Storytelling has a great potential of developing the emotional intelligence and helps the students to gain knowledge of human behavior. At the same time, it also promotes language learning by enriching learners' vocabulary and acquiring new language structures.

People tell stories for many kinds of purposes, such as for entertaining, for teaching moral value, religion and so on. Unfortunately, story-telling is rarely use in the university level since most of the lecturers think that it is not suitable with the students' age and they are probably not aware of its benefit to learning. Another problem is the lack of creativity of the lecturers and their awareness of 
the importance to raise their teaching quality. In fact that the universities students are easily loose their motivation and they often need new experience in the learning activities. Story telling provides a fun and engaging experience of teaching and learning activities.

Educators can benefit from the application of the story telling since it involves several competencies, such as speaking, listening and pronunciation. Lots of repetition during the story telling will give more practice for the students to perfect their pronunciation. Telling story is not the same with reading aloud. In the story telling, the story teller will actively explore their ability to make the listeners understand the story, by controlling their voice, pitch, tone, rhymes, and their gestures. Because it involves more on physical movement, the story telling is also suitable to be applied for the kinesthetic students. Aiex (1988) points "through story telling, the four language competencies, namely speaking, reading, writing, and listening and the language components, namely vocabulary, pronunciation and grammar can be developed”. By using story telling techniques, students can gain more benefit not only in their academic but also it helps them to appreciate more on their cultures because several stories represent some communities with their own culture.

\section{HOW TO SELECT THE STORY}

According to Burn and Broman (1975: 73) the following criteria should be followed before the teacher apply the story telling technique to the students:

a. A simple well developed plot is centered in one main sequence of events so that the students can anticipate to some degree of the outcome of events with action predominant.

b. Using repetition, rhymes, and catch phrases that the students memorize new words quickly and easily.

c. Using carefully chosen language, not using complicated words and using a large amount of direct conversation.

d. While Ellis and Brewster add the criteria for selecting the story (1991: 12-13) as follow:

e. Level of difficulty: Is the level appropriate? Not too easy? Not too difficult? 
f. Pronunciation: Does the story contain any features such as intonation that the students will enjoy imitating and improving their pronunciation?

g. Content/ Subject matter: Will the story interest the students? Is it relevant to their need? Is it amusing? Is it memorable?

h. Visuals: Do the illustration relate to the text and support the students' understanding? Are they attractive to the age of the students? Are they big enough for all the class to see?

i. Encourage participation: Is there any natural repetition to encourage participation in the text and provide pattern practice, pronunciation practice, to recycle language items and develop memory skills?

j. Motivating: Will the story motivate the students?

k. Arouse curiosity: Will the story arouse their curiosity?

1. Create positive attitudes: Will the students respond positively to the story and develop positive attitudes towards the target language, culture, and towards language learning?

$\mathrm{m}$. Language content: Is the language representative of what is spoken in the target culture? Does the story give any information about life in the target culture?

\section{METHODOLOGY}

Drawing on Alex (1988) statement "through story telling, the four language competencies, namely speaking, reading, writing, and listening and the language components, namely vocabulary, pronunciation and grammar can be developed", a questionnaire was then distributed to examine the students' perceived toward the story telling technique applied in Pronunciation Practice subject. The questionnaire was distributed to 37 students of class A 2015 which taken the Pronunciation Practice subject. Their perceived toward the story telling technique were carefully investigated.

There were 11 items were asked in the questionnaire. Each of the items in the questionnaire were analyzed and calculated then presented in the percentage to find out the students' responses toward the use of story-telling technique. The items in the questionnaire are grouped into two, namely participant responses and students' learning 
outcomes. This research is a descriptive quantitative study. The writer applied the story telling technique in the middle of the semester because at the beginning of the semester, the writer aimed to strengthen the students' basic skills in pronunciation, such as the sounds of the alphabet letters, rhyming words, some difficult sounds (ch, -th,-ed,-z,-es), as well as the phonetic symbols. This research was conducted in class A 2015 for six months of the odd semester.

\section{FINDINGS AND DISCUSSIONS}

As it shown in table 1.1 , the highest average score was in point D with the total score was 68 with the detail as follow; 32, 43\% of the population were agreed that the story telling technique was one of the interesting and fun techniques to learn Pronunciation. 56, 75\% of the population claimed that story telling helped to raise their motivation in learning Pronunciation. The illustrations and the visual media that the story tellers used were able to attract the listeners' attention and at the same time it enlightened the class atmosphere and helped to get rid off the boredom in the learning activities. While 48, 64\% of the population thought that story telling helped to build positive attitude because story telling added their moral values. The story plots which the students have created in their story telling were also helping to shape their moral, wisdom and their characters and at the same time helped them to appreciate their culture.

Moreover, 35, $13 \%$ of the population stated that story telling helped to encourage the participation during the teaching and learning activities since there were great communication between the listeners and the story tellers. There were several natural repetitions that the story tellers uttered to invite the listeners in their presentation and most of the time the story tellers asked the listeners regarding the story that they have already presented to recall the listeners' memories of the story. In spite of all the benefits of the story telling, 10, $18 \%$ of the population pointed that story telling was time consuming. It takes several preparations and quite much time in presenting. Therefore, the limitation of time was applied to overcome the problem and the lecturer assigned two of the students from the class to be the time keepers in each of the story telling presentation. This finding met the 
criteria formulated by Ellis and Brewster (1991: 12-13) that composing a story must follow these following rules;

a. Level of difficulty: Is the level appropriate?

b. Pronunciation: Does the story contain any features such as intonation that the students will enjoy imitating and improving their pronunciation?

c. Content/ Subject matter: Will the story interest the students? Is it relevant to their need? Is it amusing? Is it memorable?

d. Visuals: Do the illustration relate to the text and support the students' understanding? Are they attractive to the age of the students? Are they big enough for all the class to see?

e. Encourage participation: Is there any natural repetition to encourage participation in the text and provide pattern practice, pronunciation practice, to recycle language items and develop memory skills?

f. Motivating: Will the story motivate the students?

g. Arouse curiosity: Will the story arouse their curiosity?

h. Create positive attitudes: Will the students respond positively to the story and develop positive attitudes towards the target language, culture, and towards language learning?

i. Language content: Is the language representative of what is spoken in the target culture? Does the story give any information about life in the target culture?

Table 1.1 Participant Reaction

\begin{tabular}{|l|l|l|l|l|l|l|}
\hline No & \multicolumn{5}{|c|}{ Items } & \multicolumn{5}{c|}{ Score } \\
\cline { 3 - 7 } & & A & B & C & D & E \\
\hline $\mathrm{X}_{1}$ & $\begin{array}{l}\text { Story telling was interesting way } \\
\text { to learn Pronunciation }\end{array}$ & 0 & 0 & 1 & 12 & 24 \\
\hline $\mathrm{X}_{2}$ & $\begin{array}{l}\text { Story telling helped to raise } \\
\text { students' motivation }\end{array}$ & 0 & 0 & 1 & 21 & 15 \\
\hline $\mathrm{X}_{3}$ & $\begin{array}{l}\text { Story telling helped to create } \\
\text { positive attitude }\end{array}$ & 0 & 0 & 12 & 18 & 7 \\
\hline $\mathrm{X}_{4}$ & $\begin{array}{l}\text { Story telling helped to encourage } \\
\text { students' participation }\end{array}$ & 0 & 0 & 7 & 13 & 17 \\
\hline $\mathrm{X}_{5}$ & $\begin{array}{l}\text { The time required to do the story } \\
\text { telling was appropriate }\end{array}$ & 9 & 14 & 7 & 4 & 3 \\
\hline
\end{tabular}




\section{The Average Score (items 1 to 5)}
$\mathrm{D}_{1}=12 / 37 \times 100 \%=32,43 \%$
$\mathrm{D}_{2}: 21 / 37 \times 100 \%=56,75 \%$
$\mathrm{D}_{3}: 18 / 37 \times 100 \%=48,64 \%$
$\mathrm{D}_{4}: 13 / 37 \times 100 \%=35,13 \%$
$\mathrm{D}_{5}: 4 / 37 \times 100 \%=10,18 \%$

\section{Description:}
A : Strongly disagree
B : Disagree
C : Undecided
D : Agree
E : Strongly agree

\section{Students Learning Outcomes (items 6 to 11)}

As indicated on table 2.1, the highest average score of the story telling was in point $\mathrm{E}$ with the total score is 100 . The following are the detail of the description in point $\mathrm{E} ; 51,35 \%$ students claimed that story telling helped to improve their listening skills by listening to their peers performed the story. At the same time, 29, $72 \%$ students pointed that story telling also helped to improve their writing skills by creating the story plot and the dialogues. While 40, $54 \%$ students noted that story telling helped to raise their vocabulary because they learned several new words from the stories being presented.

Furthermore, 59, $45 \%$ students agreed that story telling activities helped to improve their speaking skills. The natural setting in the story telling helped the students to feel relax and enjoyed therefore it helped the flow of the students' speaking. Moreover, 64, $86 \%$ students stated that story telling helped to improve their pronunciation skills since there were so many repetitions in their story and it also helped to practice their intonation. The students' pronunciation skills had improved much especially on the rhyming, pitch, stress, and intonation.

Lastly, 24, 32\%students claimed that story telling helped to build their imaginative thought by creating wonderful and fun setting 
which can attract the listeners' attention and by performing the story telling as interesting as possible. This finding is in line with Aiex (1988) finding "through story-telling, the four language competencies, namely speaking, reading, writing, and listening and the language components, namely vocabulary, pronunciation and grammar can be developed".

Table 2.1 Students' Learning Outcomes

\begin{tabular}{|l|l|l|l|l|l|l|}
\hline \multirow{2}{*}{ No } & \multicolumn{1}{|c|}{ Items } & \multicolumn{5}{c|}{ Score } \\
\cline { 3 - 7 } & & \multicolumn{1}{c|}{ A } & \multicolumn{1}{c|}{ B } & C & \multicolumn{1}{c|}{ D } & \multicolumn{1}{c|}{ E } \\
\hline $\mathrm{X}_{6}$ & $\begin{array}{l}\text { Story telling helps to } \\
\text { improve listening skills }\end{array}$ & 0 & 0 & 0 & 18 & 19 \\
\hline $\mathrm{X}_{7}$ & $\begin{array}{l}\text { Story telling helps to } \\
\text { raise students } \\
\text { vocabulary }\end{array}$ & 0 & 0 & 7 & 19 & $\mathbf{1 1}$ \\
\hline $\mathrm{X}_{8}$ & $\begin{array}{l}\text { Story telling helps to } \\
\text { improve speaking skills }\end{array}$ & 0 & 0 & 5 & 17 & $\mathbf{1 5}$ \\
\hline $\mathrm{X}_{9}$ & $\begin{array}{l}\text { Story telling helps to } \\
\text { improve pronunciation } \\
\text { skills }\end{array}$ & 0 & 0 & 4 & 11 & $\mathbf{2 2}$ \\
\hline $\mathrm{X}_{10}$ & $\begin{array}{l}\text { Story telling helps to } \\
\text { improve writing skills }\end{array}$ & 0 & 2 & 3 & 8 & $\mathbf{2 4}$ \\
\hline $\mathrm{X}_{11}$ & $\begin{array}{l}\text { Story telling helps to } \\
\text { improve students } \\
\text { imaginative thought }\end{array}$ & 0 & 1 & 9 & 18 & $\mathbf{9}$ \\
\hline & Total & 0 & 3 & 28 & 91 & $\mathbf{1 0 0}$ \\
\hline
\end{tabular}

\section{Total Average}

$\mathrm{E}_{1}: 19 / 37 \times 100 \%=51,35 \%$

$\mathrm{E}_{2}: 11 / 37 \times 100 \%=29,72 \%$

$\mathrm{E}_{3}: 15 / 37 \times 100 \%=40,54 \%$

$\mathrm{E}_{4}: 22 / 37 \times 100 \%=59,45 \%$

$\mathrm{E}_{5}: 24 / 37 \times 100 \%=64,86 \%$

$\mathrm{E}_{6}: 9 / 37 \times 100 \%=24,32 \%$ 


\section{Description:}

A : Strongly disagree

B : Disagree

C : Undecided

$\mathrm{D}$ : Agree

E : Strongly agree

\section{THE STUDENTS' PRONUNCIATION ABILITIES}

After applied the story telling technique in the middle of the semester of the Pronunciation Practice subject, the final test score of the students showed a significant progress compare to their mid test score (see table 3.1). The average score of the mid test was 51, 62 while the average score was 76 .

Table 3.1 Students 'Pronunciation Score

\begin{tabular}{|l|c|l|c|c|}
\hline & & & $\begin{array}{c}\text { Mid } \\
\text { Test }\end{array}$ & $\begin{array}{c}\text { Final } \\
\text { Test }\end{array}$ \\
\hline 1. & 135300168 & Student A & 64 & 70 \\
\hline 2. & 155300011 & Student B & 50 & 67 \\
\hline 3. & 155300016 & Student C & 34 & 69 \\
\hline 4. & 155300028 & Student D & 42 & 74 \\
\hline 5. & 155300031 & Student E & 25 & 63 \\
\hline 6. & 155300033 & Student F & 44 & 70 \\
\hline 7. & 155300034 & Student G & 39 & 68 \\
\hline 8. & 155300035 & Student H & 40 & 66 \\
\hline 9. & 155300045 & Student I & 59 & 76 \\
\hline 10. & 155300047 & Student J & 60 & 80 \\
\hline 11. & 155300056 & Student K & 37 & 70 \\
\hline 12. & 155300064 & Student L & 50 & 88 \\
\hline
\end{tabular}




\begin{tabular}{|c|c|c|c|c|}
\hline 13. & 155300065 & Student $M$ & 57 & 75 \\
\hline 14. & 155300071 & Student N & 56 & 85 \\
\hline 15. & 155300076 & Student O & 30 & 70 \\
\hline 16. & 155300082 & Student P & 65 & 85 \\
\hline 17. & 155300084 & Student Q & 60 & 87 \\
\hline 18. & 155300087 & Student R & 64 & 87 \\
\hline 19. & 155300088 & Student S & 46 & 76 \\
\hline 20 . & 155300089 & Student T & 33 & 71 \\
\hline 21. & 155300096 & Student U & 26 & 66 \\
\hline 22. & 155300097 & Student V & 30 & 68 \\
\hline 23. & 155300116 & Student W & 68 & 87 \\
\hline 24. & 155300118 & Student X & 50 & 77 \\
\hline 25. & 155300120 & Student Y & 51 & 79 \\
\hline 26. & 155300121 & Student Z & 44 & 72 \\
\hline 27. & 155300122 & Student 1 & 77 & 90 \\
\hline 28. & 155300127 & Student 2 & 75 & 88 \\
\hline 29. & 155300129 & Student 3 & 45 & 67 \\
\hline 30. & 155300133 & Student 4 & 55 & 80 \\
\hline 31. & 155300134 & Student 5 & 75 & 80 \\
\hline 32. & 155300135 & Student 6 & 53 & 78 \\
\hline 33. & 155300137 & Student 7 & 65 & 75 \\
\hline 34. & 155300138 & Student 8 & 60 & 71 \\
\hline 35. & 155300139 & Student 9 & 62 & 76 \\
\hline 36. & 155300141 & Student 10 & 50 & 79 \\
\hline 37. & 155300142 & Student 11 & 69 & 82 \\
\hline
\end{tabular}




\section{Conclusions and Suggestions}

Through this study it can be seen the benefits of the story telling technique toward the students' pronunciation skills. Based on the students' perception that story telling is not only help to develop their pronunciation skills but at the same time it also helped to improve their writing, listening, and speaking skills and help to boost their vocabulary. Based on the findings that most of the students had positive attitudes toward the story telling technique and it gave a spark toward the students' motivation. The students' motivations in learning Pronunciation were increased and the class atmosphere had become more alive and less boring. The writer was positively concluded that the story telling technique gave better influence on her teaching activities, in this case is Pronunciation Practice subject. In spite of useful findings, the writer realized that the study did not longitudinally examine the students' attitudes toward the story telling technique due to the time given which is only 2 credit semester every of the odd semester. Therefore, further studies are welcome to find out the effectiveness of the story telling technique toward the students' pronunciation skills. This will give a virtual prove on the previous study done by the writer.

\section{References}

Ary, Jacobs and Razafieh (1985). Introduction to Research in Education. New York: Mc Graw Hill.

Burns, P. C. Broman, B. L. (1975). The Language Arts in Childhood Education. USA. Rond Mc. Nally College Publishing Co.

Byrne, David. (1972) Teaching Oral English. Hallow Essex. Longman. Boltman, Angela. (2001). Children's Storytelling Technologies: Differences in Elaboration and Recall. A Dissertation. Retrieved from http://id.nada,kth.se . (February $9^{\text {th }} 2016$ )

Cowan, J (1985). Effectiveness and Efficiency in Higher Education. San Francisco: Jersey B.Publisher.

Crow \& Crow (1963). Educational psychology (terjemahan psikologi pendidikan), Surabaya : Bina Ilmu 
Davis, G \& Thomas, M (1989), Effective School Effective Teacher. Boston, MA: Allyn and Bacon

Dimyathi dan Mujiono, (1999). Belajar dan Pembelajaran. Jakarta : Rineka Cipta

Dunne R \& Ted Wragg, (1996). Pembelajaran Efektif (terjemahan Anwar Yasin), Jakarta : PT.Gramedia.

Dorney, Zolta. (2001). Teaching and Researching Motivation. Essex: Pearson Education Limited.

Elliot, J. 1991. Action Research for Education Charge. Buckingham: Open University Press.

Ellis, G., Brewster. J. (1991). The Storytelling Handbook. Harmondworth: Pinguin books.

Hopkin, David.(1993). A Teacher's Guide to Classroom Research. Buckingham: Open University Press.

Jones, A. Tordova, N \& Vargo J. (2001). Improving Teaching Effectiveness Understanding and Leveraging Prior Knowledge for Student Learning. Proceeding of the $15^{\text {th }}$ Annual Conference of the International Academy for Information Management.

Klippel, Friederika, (1984). Keep talking Communicative Fluency Activities for Language Teaching. New York: Cambridge University Press.

Longman Brumfit, C. Q. Friends. (1997). Teaching English to Children. England: Longman Group Ltd.

Mason, RD.,lind, DA, \& Marhal, WG, (1988). Statistic and introduction. Florida: Harcout Branch Javanovich publisher.

Monica, Dirah. (2002). A Study on the Correlation Between the Intrinsic and Extrinsic Motivation Towards English Achievement. A Thesis. Unpublished. UNNES.

Mc Cllelland,D.C et al. (1990). The Achievement Motive. New York. Appleton Century.

Peterson, Martin. (2003). Storytelling and the Art of Teaching. Retrieved from http://exchange, state.gov/fomms/vols/vo;33/nol/p2. htm. (3 January 2016)

Pellowski. Anne. The World of Storytelling. New York :R.K. Broker 
Turnery. C et al. (1992). The Classroom Manager. Sydney: Allen and Unwin Pty Ltd.

Weiner, B. (1972). Theories of Motivation: from Mechanism through Recognition. Chicago: Morhan. 